\title{
PENGARUH PENAMBAHAN MATERIAL ALUMINA DAN KARBON AKTIF TERHADAP KEKERASAN DAN MUTU AIR PADA TEKO TEH POCI
}

\author{
Dina Ramadhini Rinaldy ${ }^{\text {a) }}$, Agus Setyo Budi ${ }^{\text {b) }}$, Widyaningrum Indrasari ${ }^{\text {c) }}$ \\ Prodi Fisika, FMIPA, Universitas Negeri Jakarta, Jl. Rawamangun Muka No. 1 RT 11 Rw 14, Pulo Gadung, \\ Kota Jakarta Timur 13220, Indonesia

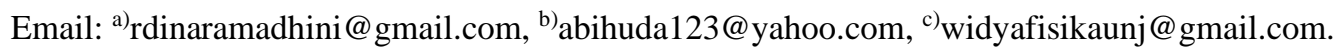

\begin{abstract}
Abstrak
Purbalingga adalah salah satu daerah pengasil teko teh poci terbesar di Indonesia. Tetapi produk yang dihasilkan rentan pecah dan memiliki zat terlarut sehingga kualitas produk cukup rentan dalam ketatnya persaingan pasar. Maka dari itu dilakukan inovasi peningkatan kualitas teko teh poci dengan memperkuat sifat kekerasan dan mengurangi zat terlarut pada teko teh poci dengan menambahkan alumina dan karbon aktif ke dalam tanah liat sebagai bahan dasar pembuatan teko teh poci. Tujuan dari paper ini adalah mengetahui pengaruh penambahan alumina dan karbon aktif ke dalam tanah liat. Metode yang digunakan pada paper ini adalah studi literatur terhadap penelitian terkait. Hasil yang didapat adalah material alumina akan menambahkan kekerasan material tanah liat dengan menaikkan nilai densitas dan mengurangi porositas sehingga material semakin padat. Semakin tinggi konsentrasi alumina dan suhu yang digunakan akan menaikan kekerasan material. Sedangkan penambahan karbon aktif ke dalam tanah liat akan menaikan porositas seiring dengan meningkatnya konsentrasi yang digunakan dan menghasilkan uji TDS yang lebih baik.
\end{abstract}

Kata kunci: Tanah liat, alumina, karbon aktif, kekerasan, zat terlarut.

\begin{abstract}
Purbalingga is one of the biggest teapot producers in Indonesia. But the products are fragile and have dissolved solids, so the quality of the products is quite vulnerable in the intense market competition. Therefore an innovation was made to improve the quality of the teapot by strengthening hardness material and reduce dissolved solids by adding alumina and activated carbon into the clay as the teapot basic material. The purpose of this paper is to determine the effect of addition alumina and activated carbon into clay. The method used in this paper is study of literature on related researches. The result is alumina material will increase the hardness of clay by increasing the density and reducing porosity so the material becomes denser. The higher concentration of alumina and the temperature used will increase the hardness of material. Addition of activated carbon will increase porosity as more as the increasing of concentration that are used and produce a better TDS test.
\end{abstract}

Keywords: Clay, alumina, activated carbon, hardness, dissolved solids. 


\section{PENDAHULUAN}

Purbalingga adalah salah satu daerah penghasil tanah liat dan sebagian besar masyarakatnya bermata pencaharian sebagai pengrajin gerabah. Di daerah Purbalingga banyak masyarakatnya yang memproduksi teko teh poci yang terbuat dari tanah liat atau gerabah karena daerah ini memiliki sumber daya alam tanah liat yang melimpah. Tanah liat atau gerabah ini kemudian diolah menjadi berbagai macam jenis seperti teko teh poci, gelas, guci, keramik dan hiasan lainnya.

Teko teh poci adalah suatu wadah yang digunakan untuk menyeduh teh secara tradisional yang masih digemari oleh masyarakat Indonesia sampai dengan sekarang. Tetapi teko ini memiliki beberapa kekurangan diantaranya memiliki sifat yang rentan pecah dan memiliki zat terlarut.

Tanah liat merupakan tanah yang berukuran mikro sampai dengan sub mikro yang berasal dari pelapukan unsur-unsur kimiawi penyusutan batuan [1]. Tanah liat tersusun dari kelompok alumina silikat seperti $\mathrm{Al}, \mathrm{Fe}, \mathrm{Mg}$, dan $\mathrm{Si}$ dimana memiliki sifat plastis dan akan menjadi keras jika dipanaskan pada suhu tinggi [2].

Alumina (Al2O3) adalah material yang banyak digunakan dalam berbagai aplikasi karena sifat yang dimilikinya. Alumina memiliki sifat yang keras, kekuatan yang tinggi, isolasi elektrik yang baik dan tahan terhadap temperatur [3] karena memiliki titik lebur yang tinggi. Selain itu alumina memiliki ketahanan abrasi dan korosi yang tinggi [4].

Karbon aktif atau arang aktif adalah padatan berpori yang umumnya berasal dari senyawasenyawa organik seperti sekam padi, tempurung kelapa, serbuk gergaji dan lain lain yang telah diproses atau diaktifkan [2]. Karbon aktif digunakan untuk mengolah air minum, menghilangkan bahan kimia, bau dan polutan yang beracun bagi manusia. Karbon akif menggunakan prinsip adsorpsi untuk memurnikan air yang terkontaminasi. Karbon aktif memiliki daya tarik yang kuat untuk logam berat, senyawa organik dan senyawa non-polar lainnya [5].

Salah satu pengujian yang digunakan untuk menguji hasil air menggunakan karbon aktif adalah uji TDS (Total Dissolved Solids). Aplikasi dasar pengujian TDS pada umumnya melingkupi mutu air tawar, aliran sungai dan danau. TDS digunakan sebagai acuan atau petunjuk pengukuran karakteristik air dari kontaminasi zat-zat kimia atau zat-zat yang terlarut di dalam air [6].

Uji tekan atau hardness test adalah pengujian yang dilakukan pada sampel guna mengetahui nilai kekerasan suatu material. Nilai kekerasan pada suatu material tidak hanya bergantung dengan material yang diuji, melainkan juga dipengaruhi oleh metode pungujian yang digunakan. Ada beberapa jenis uji kekerasan yang sering dilakukan pada material yaitu ball identation test (Brinnel), cone and ball identation test (Rockwell), dan pyramida identation test (Vickers). Yang membedakan antara metode ini adalah indentor dan beban uji yang akan digunakan [7].

Seiring dengan kemajuan teknologi di bidang material maka dilakukan berbagai upaya untuk mengembangkan dan mendapatkan material yang memiliki kualitas lebih baik. Maka dari itu ditambahkan material lain ke dalam bahan dasar material teko teh poci untuk menghasilkan teko teh poci yang lebih baik yaitu material alumina dan karbon aktif untuk menambahkan nilai kekerasan dan mengurangi zat terlarut pada teko teh poci. Pada artikel ini dilakukan analisa pengaruh penambahan material alumina dan karbon aktif ke dalam tanah liat sebagai bahan pembuatan teko teh poci dengan menggunakan hasil dari penelitian yang telah dilakukan sebelumnya.

\section{METODOLOGI}

Pada artikel dilakukan analisa pengaruh penambahan alumina dan karbon aktif ke dalam tanah liat sebagai bahan dasar teko teh poci dengan metode studi literatur terhadap penelitian terkait yang telah dilakukan sebelumnya. Penelitian pertama adalah penelitian yang telah dilakukan oleh Hamzah dkk pada penelitian ini bahan yang digunakan adalah serbuk tanah liat yang dikalsinasi pada suhu $800{ }^{\circ} \mathrm{C}$ selama 30 menit. Tanah liat yang telah dikalsinasi dicampur dengan alumina dengan komposisi $0 \%$, $15 \%, 30 \%, 45 \%$ dan 60\%. Campuran tanah liat dan alumina ditambahkan alkohol agar campuran menjadi homogen, campuran selanjutnya dicetak dengan tekanan $50 \mathrm{MPa}$ dan sintering pada temperatur $1000^{\circ} \mathrm{C}, 1100^{\circ} \mathrm{C}, 1200^{\circ} \mathrm{C}$ dan $1300^{\circ} \mathrm{C}$.

Penelitian selanjutnya yang telah dilakukan oleh Kool dkk, meterial yang digunakan pada penelitian ini adalah Aluminium isopropaxide $(\mathrm{Al}(\mathrm{O}-\mathrm{i}-\mathrm{Pr}) 3)$ (AIP) digunakan sebagai sumber untuk 
alumina dan tanah liat yang berasal dari India. AIP ditambahakan $100 \mathrm{ml}$ millipore water dan diaduk sampai tercampur merata dengain air. Tanah liat dimasukkan ke dalam AIP yang telah diolah dan diaduk. Campuran tanah liat dan alumina yang telah disintesis selanjutnya dilakukan sintering pada suhu $1000^{\circ} \mathrm{C}, 1100^{\circ} \mathrm{C}, 1200^{\circ} \mathrm{C}, 1300^{\circ} \mathrm{C}$ dan $1400^{\circ} \mathrm{C}$ selama 5 jam.

Penelitian selanjutnya adalah penelitian yang dilakukan oleh Ervina dkk, pada penelitian ini digunakan material tanah liat, zeolit dan karbon aktif untuk membuat membran keramik. Komposisi yang digunakan pada penelitian ini adalah $10 \%$ tanah liat ( $90 \%$ zeolit - karbon aktif) dengan variasi karbon aktif berkisar 0\%-20\% dengan kenaikan 5\% untuk setiap sampel.

\section{HASIL DAN PEMBAHASAN}

\section{Penambahan alumina}

Penambahan material alumina ke dalam tanah liat sebagai bahan dasar pembuatan teko teh poci dapat dilihat dari penelitian yang telah dilakukan sebelumnya oleh Hamzah dkk. Dari hasil yang didapat penambahan material alumina ke dalam tanah liat mempengaruhi nilai densitas yang dimiliki oleh material. Hasil data menunjukkan semakin besar komposisi material alumina yang ditambahkan ke dalam tanah liat akan menghasilkan nilai denstitas yang lebih tinggi [8]. Densitas merupakan nilai kepadatan pada suatu material. Semakin tinggi nilai densitas artinya semakin kuat ikatan yang dimiliki antar partikel sehingga material semakin padat. Nilai densitas juga berhubungan dengan temperatur yang digunakan. Semakin tinggi temperatur yang digunakan akan menyebabkan material bercampur dengan unsur-unsur yang terkandung di dalam keramik. Nilai densitas suatu material semakin tinggi jika ikatan antar partikelnya semakin kuat dan menunjukkan kerapatan yang tinggi [9]. Nilai densitas pada suatu material berbanding terbalik dengan nilai porositasnya. Semakin besar nilai densitas suatu material maka semakin kecil nilai porositas yang dimilikinya [4][10][11].

Porositas adalah banyaknya ruang kosong yang terdapat pada struktur pembentuk suatu material [2]. Pada penelitian yang dilakukan oleh Gonçalves dkk [12] hasil yang didapat pada komposit campuran alumina dan tanah liat memiliki nilai porositas $\sim 37.5 \%$ dengan temperatur sintering $900^{\circ} \mathrm{C}$. Nilai porositas terus berkurang seiring dengan tingginya temperatur yang digunakan yaitu $\sim 30 \%$ saat temperatur $1100^{\circ} \mathrm{C}, \sim 25 \%$ saat temperatur $1200^{\circ} \mathrm{C}, \sim 15 \%$ pada $1300^{\circ} \mathrm{C}$ dan memiliki nilai porositas terkecil yaitu $\sim 6.25 \%$ saat menggunakan temperatur $1400^{\circ} \mathrm{C}$. Selama proses sintering partikel di dalam material akan saling mengikat karena terjadinya proses difusi. Semakin tinggi temperatur yang digunakan maka semakin besar pergerakan difusi yang terjadi sehingga dapat mendorong kekosongan atau porous ke arah butir dan menyebabkan ukuran pori mengecil [4]. Hal inilah yang menyebabkan sehingga jumlah porositas pada suatu material akan berkurang dan menghasilkan kepadatan seiring dengan semakin tinggi temperatur yang digunakan [3][11]. Hal ini juga terjadi pada penelitian yang lakukan oleh Gonçalves dkk [12]. Semakin tinggi nilai densitas tentu akan mempengaruhi sifat mekanik dari material tersebut. Hal ini dapat dilihat dari hasil uji kekerasan pada campuran alumina dan tanah liat.

Hasil uji kekerasan Vickers pada komposit campuran material alumina dan tanah liat telah dilakukan oleh Kool dkk. Pada penelitian ini menghasilkan nilai kekerasan material akan semakin tinggi seiring dengan kenaikan temperatur yang digunakan. Sampel komposit campuran alumina dan tanah liat memiliki nilai kekerasan vickers $\sim 0.9 \mathrm{GPa}$ setelah proses sintering pada suhu $1000^{\circ} \mathrm{C}$ dan memiliki nilai tertinggi yaitu $\sim 4,5 \mathrm{GPa}$ dengan suhu sintering $1400^{\circ} \mathrm{C}$. Tentu hal ini berhubungan dengan nilai densitas dan besarnya butir yang dimiliki oleh material tersebut. Semakin tinggi temperatur sintering akan menghasilkan kepadatan dan semakin besar ukuran butir yang terdapat pada material komposit [11]. Semakin tinggi temperatur sintering maka campuran material alumina dan tanah liat akan mencapai fase mullite dan memiliki kristalinisasi yang lebih tinggi sehingga meningkatkan sifat mekanik material [12].

Pengaruh penambahan alumina ke dalam tanah liat dalam mempengaruhi kekerasan material juga dapat dilihat dari hasil uji SEM yang telah dilakukan oleh Hamzah dkk. Pada hasil uji SEM terlihat semakin besar komposisi alumina dan semakin tinggi temperatur yang digunakan terlihat permukaan yang lebih rapat karena memiliki densitas yang tinggi dan ukuran butir yang lebih besar [8]. Hasil uji SEM dengan komposisi alumina dan temperatur yang rendah terdapat porositas seperti butir kosong 
pada hasil perbesaran permukaan sampel [12]. Nilai porositas akan semakin berkurang seiring dengan semakin tinggi komposisi alumina dan temperatur yang digunakan [13].

\section{Penambahan karbon aktif}

Komposit filter air berupa tanah liat yang ditambahkan berbagai jenis karbon aktif atau bahan aditif sudah banyak dilakukan saat ini. Hal ini dikarenakan komposit tanah liat menjadi material yang menjanjikan untuk menghilangkan logam berat, antibiotik, senyawa fenolik, bau, dan pewarna dari berbagai limbah industri [14].

Pengaruh penambahan karbon aktif ke dalam tanah liat dilihat dari hasil yang didapat pada penelitian Ervina dkk mempengaruhi nilai densitas dan porositas. Semakin besar karbon aktif yang digunakan pada campuran keramik filter semakin besar porositas material tersebut. Pada komposisi karbon aktif 5\% besar porositas adalah $43.3 \%$ dan memiliki nilai porositas $61.5 \%$ dengan komposisi $20 \%$ karbon aktif [2]. Hal ini juga terjadi pada penelitian yang telah dilakukan sebelumnya. Penambahan karbon aktif ke dalam campuran keramik akan mengurangi nilai densitas dan meningkatkan nilai porositas [15][16]. Hal ini dikarenakan semakin besar konsentrasi karbon aktif yang digunakan maka akan menghasilkan ukuran pori yang lebih besar yang dihasilkan dari karbon aktif yang terbakar saat proses pembakaran sampel [15]. Besarnya ukuran pori yang dihasilkan bergantung dengan banyaknya komposisi karbon aktif yang digunakan pada material. Semakin tinggi komposisi karbon aktif yang digunakan maka semakin banyak pori yang dihasilkan pada hasil pengujian SEM [2]. Selain banyaknya komposisi karbon aktif yang digunakan, besarnya nilai porositas juga dipengaruhi oleh besarnya ukuran partikel karbon aktif yang digunakan. Hal ini dapat dilihat pada penelitian yang dilakukan oleh Widayati dkk semakin besar ukuran karbon aktif maka semakin besar porositas yang terdapat pada material karena rongga antar partikel akan semakin besar seiring dengan besarnya ukuran partikel karbon aktif yang digunakan [17].

Sedangakan untuk pengaruh penambahan konsentrasi karbon aktif pada tanah liat ditinjau dari hasil TDS (Total Dissolved Solids) untuk mengurangi zat terlarut dalam air dapat dilihat dari penelitian yang telah dilakukan menghasilkan bahwa semakin besar konsentrasi karbon aktif yang digunakan akan menghasilkan kadar TDS yang semakin menurun artinya semakin besar konsentrasi karbon aktif maka semakin sedikit zat terlarut yang terdapat dalam air. Hal ini juga terjadi pada penelitian yang dilakukan oleh Nurmalasari dkk dan Saifuddin dkk [6][14]. Hal ini dikarenakan karbon aktif akan menggunakan prinsip adsorpsi atau penyerapan untuk memurnikan air yang terkontaminasi dengan menggunakan adhesi ke permukaan polutan sehingga polutan yang terdapat dalam air akan ditahan pada pemukaan karbon yang telah aktif [5].

\section{SIMPULAN}

Berdasarkan analisa yang telah dilakukan dapat disimpulkan bahwa penambahan alumina ke dalam tanah liat sebagai bahan dasar teko teh poci akan menambahkan nilai kekerasan material. Hal ini dikarenakan nilai densitas akan semakin tinggi seiring dengan banyaknya komposisi alumina dan tingginya temperatur yang digunakan. Tingginya nilai densitas atau kerapatan akan mengurangi nilai porositas sehingga berpengaruh pada sifat mekanik material. Sedangkan untuk penambahan karbon aktif ke dalam tanah liat diketahui semakin besar konsentrasi karbon aktif akan menurunkan nilai densitas dan menaikan nilai porositas. Semakin besar konsentrasi karbon aktif yang digunakan akan menghasilkan hasil uji TDS yang lebih baik artinya semakin sedikit zat terlarut yang terdapat dalam air.

\section{REFERENSI}

[1] L. Yohanes Jones et al., "Pemanfaatan Lempung Sebagai Bahan baku gerabah," Pros. Semin. Nas. Sain dan Teknol. Terap, Bahan Lempung, pp. 543-554, 2015.

[2] E. P. Sari, A. S. Budi and E. Budi, "Pengaruh aditif arang batok kelapa terhadap densitas dan porositas memberan keramik berbasis zeolit dan tanah lempung," Semin. Nas. Fis, pp. 67-71, 2012. 
[3] Bisioni et al., "Sifat kuat tekan dan impak komposit abu sekam padi/alumina," J. Mek, vol. 10, no. 1, pp. 955-969, 2019.

[4] J. Raharjo, S. Rahayu and T. Mustika, "Pengaruh Tingkat Kemurnian Bahan Baku Alumina Terhadap Temperatur Sintering dan Karakteristik Keramik Alumina," Pros. Semin. Nas. Tek. Kim. "Kejuangan" Pengemb. Teknol, Kim. untuk Pengolah, Sumber Daya Alam Indones, pp. $1-7,2015$.

[5] Y. K. O and M. M. O, "Development and performance evaluation of a portable household ceramic water filter with activated carbon and magnetic treatment unit," Int. J. Environ. Sci. Technol, no. 0123456789, 2020, doi: 10.1007/s13762-020-02747-4.

[6] D. P. Nurmalasari, A. Yuliestyan and I. G. S. Budiaman, "Influence of Sodium Carbonate Activator Concentration and Activated Carbon Size on The Reduction of Total Dissolved Solid ( TDS ) and Chemical Oxygen Demand ( COD ) of Water," pp. 1-7, 2019.

[7] M. F. Kumayasari and A. I. Sultoni, "Studi Uji Kekerasan Rockwell Superficial VS Micro Vickers," Teknol. Proses dan Inov. Indrustri, vol. 2, no. 2, 2017.

[8] H. M. S, "Kekuatan impak komposit clay dan alumina untuk aplikasi fire brick," J. Mek, vol. 8, no. 1, pp. 716-720, 2017.

[9] A. I. Imran et al., "Analisa porositas dan kekuatan bending keramik matriks komposit berbahan dasar tanah liat dan pasir lokal," pp. 413-418, 2016.

[10] R. B. Choudary, A. Burri and K. V. P. Priya, "Materials Today : Proceedings Fabrication and testing of clay cups," Mater. Today Proc, no. 40, 2020, doi: 10.1016/j.matpr.2020.01.159.

[11] A. Kool et al., "Applied Clay Science Mechanical, dielectric and photoluminescence properties of alumina - mullite composite derived from natural Ganges clay," Appl. Clay Sci, vol. 114, pp. 349-358, 2015, doi: 10.1016/j.clay.2015.06.021.

[12] W. P. Gonçalves et al., "Applied Clay Science Microstructural, physical and mechanical behavior of pastes containing clays and alumina waste," Appl. Clay Sci, vol. 200, pp. 1-7, 2016, doi: 10.1016/j.clay.2016.12.026.

[13] J. Ma et al., "High-performance macro-porous alumina-mullite ceramic membrane supports fabricated by employing coarse alumina and colloidal silica," Ceram. Int, vol. 45, no. 14, pp. 17946-17954, 2019, doi: 10.1016/j.ceramint.2019.06.012.

[14] H. Han et al., "A critical review of clay-based composites with enhanced adsorption performance for metal and organic pollutants," vol. 369, 2018, pp. 780-796, 2019, doi: 10.1016/j.jhazmat.2019.02.003.

[15] A. N. Mahfuzin, S. M. B. Respati and M. Dzulfikar, "Analisis filter keramik berpori berbasis zeolit alami dan arang sekam padi dalam menurunkan kandungan partikel air sumur galian," Momentum, vol. 16, no. 1, pp. 63-68, 2020.

[16] S. Saifuddin, E. Elisa and M. Sami, "Efisiensi Kinerja Membran Keramik Tanah Liat \& Zeolit Aktif Sebagai MediaFilter Untuk Filtrasi Air Sungai," vol. 2, no. 1, pp. 240-247, 2018.

[17] Widayati et al., "Pengaruh Ukuran Partikel Bentonit dan Arang Kayu pada Pembuatan Keramik Filter," Pros. Semin. Nas. Tek. Kim. "Kejuangan” Pengemb, Teknol. Kim. untuk Pengolah. Sumber Daya Alam Indones, no. 0553, pp. 1-8, 2016. 
